\title{
Tropical coral reef system hydrodynamics in the western Gulf of Mexico
}

\author{
Mayra Lorena Riveron-Enzastiga ${ }^{1}$, Noel Carbajal ${ }^{2}$, David Salas-Monreal ${ }^{3}$ \\ ${ }^{1}$ Cuerpo Academico de Analisis y Sintesis de Zona Costera, Universidad Veracruzana, Boca del Rio, Ver. 94290, Mexico. \\ ${ }^{2}$ Instituto Potosino de Investigacion en Ciencia y Tecnologia, Camino a La Presa de San José 2055, Lomas 4a. Sección, \\ San Luis Potosí, S.L.P. 78216, Mexico. \\ ${ }^{3}$ Instituto de Ciencias Marinas y Pesquerias, Universidad Veracruzana, Hidalgo 716, Boca del Rio, Ver. 94290, Mexico. \\ E-mail: davsalas@uv.mx
}

\begin{abstract}
Summary: The acoustic Doppler current profiler, temperature, salinity and density data set were recorded monthly over the course of a year in a tropical coral reef system to elucidate the effects of abrupt bathymetric changes on current variability and surface temperature over time. A minimum of five transect repetitions were performed during one diurnal tidal cycle each month during the year 2008. According to the empirical orthogonal functions, the dominant terms were advection and friction due to the shallowness of the system and the relatively short continental shelf located in front of the Port of Veracruz (Mexico). The data showed the dominance of the northwest-southeast current velocity components (parallel to the coast) attributed to the winds. The southeastward current velocity was the dominant component throughout the year, followed by the northwestward current velocity component. The data suggested that coral reefs produce current rectification near the shallow reef areas (1 m depth). No correlation existed between surface temperature and the chlorophyll- $a$ levels throughout the year. Residual current velocities throughout the year never reached more than $50 \mathrm{~cm} \mathrm{~s}^{-1}$ during the sampling periods, and the surface temperature varied from 21 to $30^{\circ} \mathrm{C}$, with the highest temperature being observed near the coast and reefs. Finally there was a direct correlation of the northeasterly and strong northwesterly winds with the well-mixed cold-salty water column in the reef area.
\end{abstract}

Keywords: flow dynamics; tropical coral reef; current velocities; flow rectification; Veracruz Reef System.

Hidrodinámica de un sistema arrecifal coralino en el oeste del Golfo de México

Resumen: Las corrientes marinas, la temperatura del agua, la salinidad y densidad del mar fueron registradas mensualmente a lo largo de un año, en un sistema de arrecifes coralinos del Golfo de México, para obtener los efectos de los cambios batimétricos sobre la variabilidad de las corrientes marinas y de la temperatura superficial. Se realizó un mínimo de cinco repeticiones, para cada transecto durante un ciclo de marea diurna, de forma mensual durante el 2008. De acuerdo con las Funciones Ortogonales Empíricas (EOF), los términos dominantes fueron la advección y la fricción. Esto se debió a la poca profundidad del sistema $(<45 \mathrm{~m})$ y a la plataforma continental, relativamente corta, situada frente al puerto de Veracruz (México). Los datos mostraron que la componente de velocidad dominante en el sistema es paralela a la costa (sureste-noroeste) principalmente debido al régimen de vientos. La dirección de la velocidad de la corriente dominante fue hacia el sureste seguida por el componente noroeste. Los datos sugieren que los arrecifes de coral producen una rectificación de la corriente cerca de las zonas de arrecifes poco profundas $(1 \mathrm{~m}$ de profundidad). No se encontró en este estudio una correlación entre la temperatura de la superficie y los niveles de clorofila- $a$ lo largo del año. Las velocidades de las corriente residual a lo largo del año no rebasaron los $50 \mathrm{~cm} \mathrm{~s}^{-1}$ durante los períodos de muestreo, y la temperatura superficial variaron de 21 a $30^{\circ} \mathrm{C}$. La temperatura más alta se observó cerca de la costa y los arrecifes. Por último, existe una correlación directa entre los vientos del noroeste con la columna de agua mezclada (fría y salada) en el área muestreada.

Palabras clave: dinámica costera; arrecife de coral tropicales; rectificación de las velocidades de las corrientes; efectos batimétricos; Sistema Arrecifal Veracruzano.

Citation/Como citar este artículo: Riveron-Enzastiga M.L., Carbajal N., Salas-Monreal D. 2016. Tropical coral reef system hydrodynamics in the western Gulf of Mexico. Sci. Mar. 80(2): 237-246. doi: http://dx.doi.org/10.3989/scimar.04259.15B

Editor: J. Font.

Received: April 22, 2015. Accepted: January 20, 2016. Published: March 16, 2016.

Copyright: (C) 2016 CSIC. This is an open-access article distributed under the Creative Commons Attribution-Non Commercial Lisence (by-nc) Spain 3.0. 


\section{INTRODUCTION}

Marine ecosystems, particularly those around coastal areas, such as coral reefs, have been studied to understand sediment transport (Agardy 2000, Salas-Monreal et al. 2009b), zooplankton and coral larvae dispersion (Holliday and Pieper 1980, Becerro et al. 2006, ChaconGomez et al. 2013) and the variability in spatial and temporal hydrodynamics and currents (Goreau and Hayes 1994, Salas-de-Leon et al. 2004a, Wilkinson and Souter 2008, Salas-Monreal et al. 2009b). Most oceanographic studies in the western Gulf of Mexico have been performed by analysing the processes that occur in a range of hundreds of kilometres (Zavala-Hidalgo et al 2003, Monreal-Gomez et al. 2004). However, this scale is not appropriate to study coral reef areas where the dispersion of suspended particles is provided locally in tens of metres (Salas-Monreal et al. 2009b). At this scale, eddies are generated by current rectification (Storlazzi et al. 2006), which is attributed to coral reefs that act as natural barriers owing to their bathymetric changes. Cyclonic eddies generate highly productive areas owing to the deep high-nutrient cold water pumping to the surface (Salas-de-Leon et al. 2004b, Salas-Monreal et al. 2009b), whereas anticyclonic eddies are oligotrophic (Biggs 1992). Eddies are one of the most important factors regarding the distribution of productivity areas, sedimentation and vertical water movements. They are also responsible for the turbulent flow that reduces light penetration (Salas-Monreal et al. 2009b).

The Veracruz Reef System (VRS) is a Marine National Park in the Gulf of Mexico (Fig. 1) influenced by diurnal tides (Salas-Pérez et al. 2008, 2012). The reefs are divided by the Jamapa River discharge, which generates pressure gradients and advection. The river's maximum discharges occur during the summer, whereas it is considered a salty river during the winter. The oblong shapes of the reefs, which are situated in a northwest-southeast direction, are mostly attributed to the currents and wind patterns (Salas-Monreal et al. 2009b). Salas-Pérez et al. (2012) found that the dominant component of the wind during the summer season was parallel to the coast (southeasterly), whereas Velasco and Winant (1996) showed that the dominant winds in the area over a year are northerlies, northeasterlies, easterlies or southeasterlies. The wind-induced currents should dominate local dynamics because winds reach velocities of up to $100 \mathrm{~km} \mathrm{~h}^{-1}$ during the winter and up to $80 \mathrm{~km} \mathrm{~h}^{-1}$ during the summer. These winds can be sustained for up to 3 days.

The goal of this study was to advance our understanding of the yearlong hydrodynamics of a tropical coral reef system in the western Gulf of Mexico, a shallow reef area under the influence of strong winds and seasonal river discharges. In situ data were collected during the year 2008 to describe any possible current and surface temperature variations during the year.

\section{MATERIALS AND METHODS}

Current profiles from a 300-kHz acoustic Doppler current profiler (ADCP) were obtained in the VRS, a

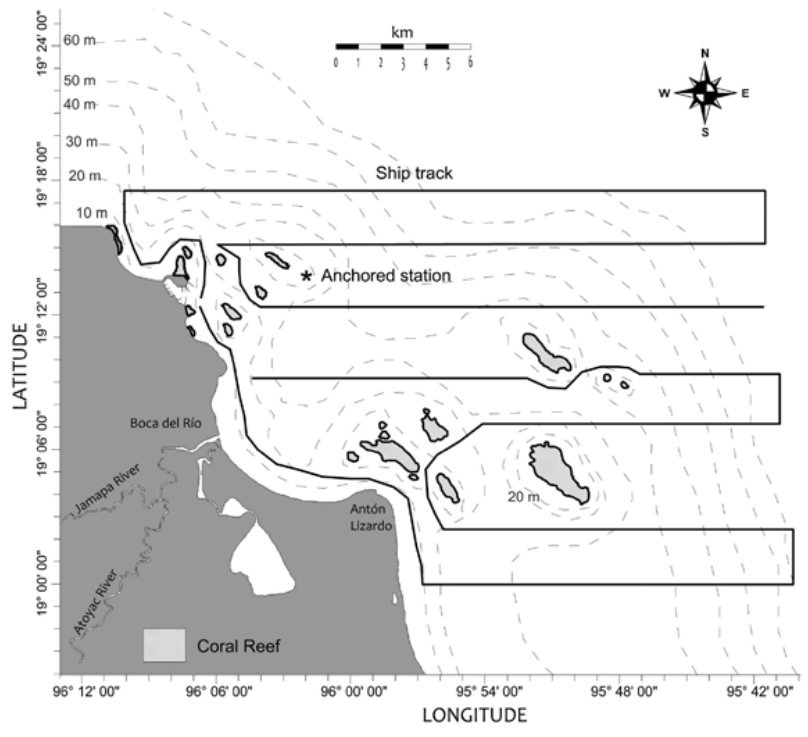

Fig. 1. - The bathymetry of the Veracruz Reef System is represented with dashed lines, the ship track of both vessel-mounted ADCPs are represented with a solid black line, the anchored station is represented with an asterisk and the four ADP locations in the southeastern coral reef area are represented with numbers $(1,2,3,4)$.

shallow $(<45 \mathrm{~m})$ coastal area with abrupt bathymetric changes in the western Gulf of Mexico, to elucidate the yearlong hydrodynamics and the effect of current variation in a tropical coral reef area. The ADCP ping rate was averaged every $5 \mathrm{~s}$, yielding a horizontal resolution of approximately $15 \mathrm{~m}$ and a vertical resolution of $1 \mathrm{~m}$. The ADCP compass was calibrated using a global positioning system data set following the methods of Trump and Marmorino (1997). The vessel-mounted ADCP was towed every two months during a diurnal tidal cycle in 2008. A minimum of five transect repetitions (Fig. 1) of velocity, temperature, salinity, chlorophyll-a levels and density profiles were continuously collected along the reefs from January to December 2008 to obtain the residual current pattern and the yearlong hydrographic data set. The transect repetitions were performed at a speed of $3 \mathrm{~m} \mathrm{~s}^{-1}$ near the reefs and $5 \mathrm{~m} \mathrm{~s}^{-1}$ in open waters during a diurnal tidal cycle. All of the data were positioned with a global positioning system (GPS) synchronized with the ADCP. Two vessel-mounted ADCPs were used concurrently to cover the entire area, with the first vessel covering the northern reef area and the second vessel covering the southern reef area. Both of the ADCPs were programmed equally and started and ended their transects at approximately the same time. When the vessel-mounted ADCPs reached the end of the transect, they followed the same track back to the start of the transect to begin again. The tidal and harmonic signals were separated using a harmonic analysis method (Salas-Monreal et al. 2009a).

To obtain homogeneous maps of currents and water temperature, an objective analysis process was performed using a triangular interpolation method with linear interpolations (Emery and Thompson 2001, Salas-de-Leon et al. 2004a, b). Density profiles were ob- 

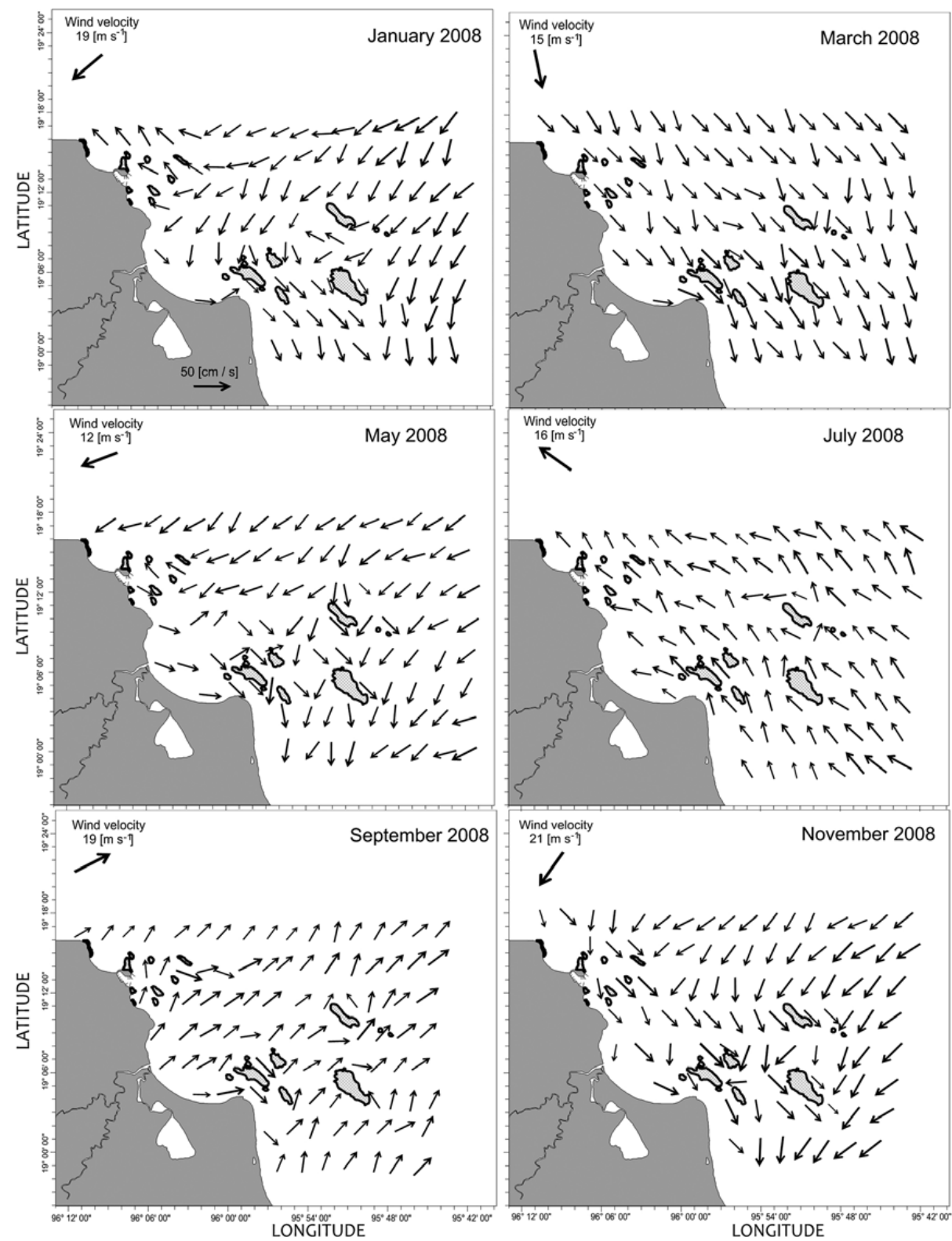

Fig. 2. - Residual surface (1 m depth) current velocities and the two-day average wind velocity on 18 January, 21 March, 16 May, 18 July, 19 September and 21 November 2008.

tained monthly from a conductivity-temperature-depth recorder (SeaBird-19 CTD) at the anchored station and at the ends and middle section of the transects (Fig. 1). Drift buoys were also deployed each month to obtain the 1-m-depth current trajectories. The buoys had an integrated Garmin GPS to locate them every $30 \mathrm{sec}-$ ond. The empirical orthogonal functions (EOF) were obtained to elucidate the principal modes of the current speed, calculated using the yearlong time series of each transect point. Finally, the modes were correlated with the acceleration terms of the momentum equation. To describe the effects of the abrupt bathymetric changes on current rectification, four points were selected: one on each side of the reef at a distance of $500 \mathrm{~m}$ perpendicular to the reef coast (Fig. 1). The current for each point was rotated to have the primary components parallel and perpendicular to the reef coast, leaving the $x$-axis perpendicular and the $y$-axis parallel to the coast. Each current profile was recorded with a 600$\mathrm{kHz}$ Nortek Acoustic Doppler Profiler (ADP) with a vertical resolution of $1 \mathrm{~m}$. In addition, a time series of water velocities, density, chlorophyll- $a$ levels, salinity and temperature were recorded from 6 January to 10 December 2008 to elucidate any seasonal or annual variability (Fig. 1).

\section{RESULTS AND DISCUSSIONS}

\section{Current pattern}

The residual flow was separated from the tidal signal using a harmonic analysis that was obtained once every two months from the repetition of the five transects during the 25 -h periods. The surface residual flow suggested the dominance of the southward current component from November to May 2008, and a reversal of the flow during 

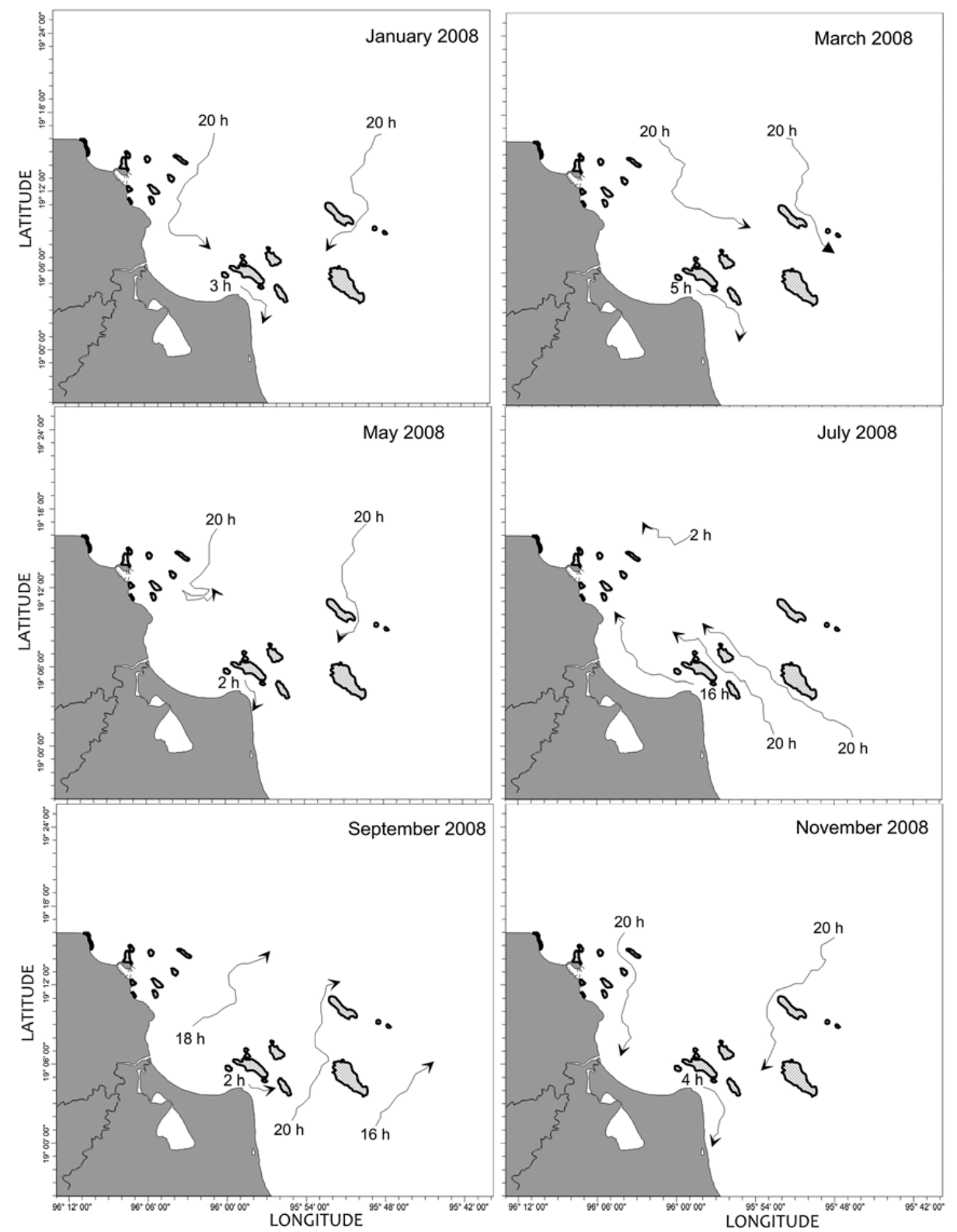

Fig. 3. - Surface (1 m depth) drift buoy trajectories and amount of time between their release and collection on 18 January, 21 March, 16 May, 18 July, 19 September and 21 November 2008.

the summer (Fig. 2) with some variation (east-west) owing to wind velocities. Since most of the coral spawning takes place during the summer, it was suggested that the southern coral reef areas should be one of the sources of coral larvae in the western Gulf of Mexico (Salas-Pérez and Granados-Barba 2008). During northeasterly wind conditions, the water flow accelerated at the constriction between the two reef areas and between the continuous reefs because the same amount of water has to pass through a smaller area. Current velocities observed in the southern reef area were higher than those observed in the northern area, a result that was not expected based on continuity, which would suggest an acceleration of the flow due to the shallowness of the northern reef area and the proximity between reefs (Fig. 1). In this study the differences in velocities of the two reef areas was attributed to bottom friction. The depth of the southern reef area is $45 \mathrm{~m}$, whereas the depth of the northern reef area is only $25 \mathrm{~m}$. As observed with the surface current patterns (Fig. 2), the flow rectified its trajectory near the reefs because of topographic constriction, as observed using the objective analysis process performed with a triangular interpolation method with linear interpolations (Salasde-Leon et al. 2004a, b). Current rectification was also observed with the drift buoys (Fig. 3), which rectified their trajectories near the reefs, moving parallel to the reefs regardless of the wind velocity and season of the year. The drift buoys showed a dominant southward current component from November to May 2008, and the current reversed during the summer. The reversal of the currents is mostly attributed to the Gyre of Campeche and to remote winds, a mesoscale behaviour that affects the western Gulf of Mexico (Zavala-Hidalgo et al 2003, Dubranna et al. 2011, Salas-Pérez et al. 2012, Allende- 

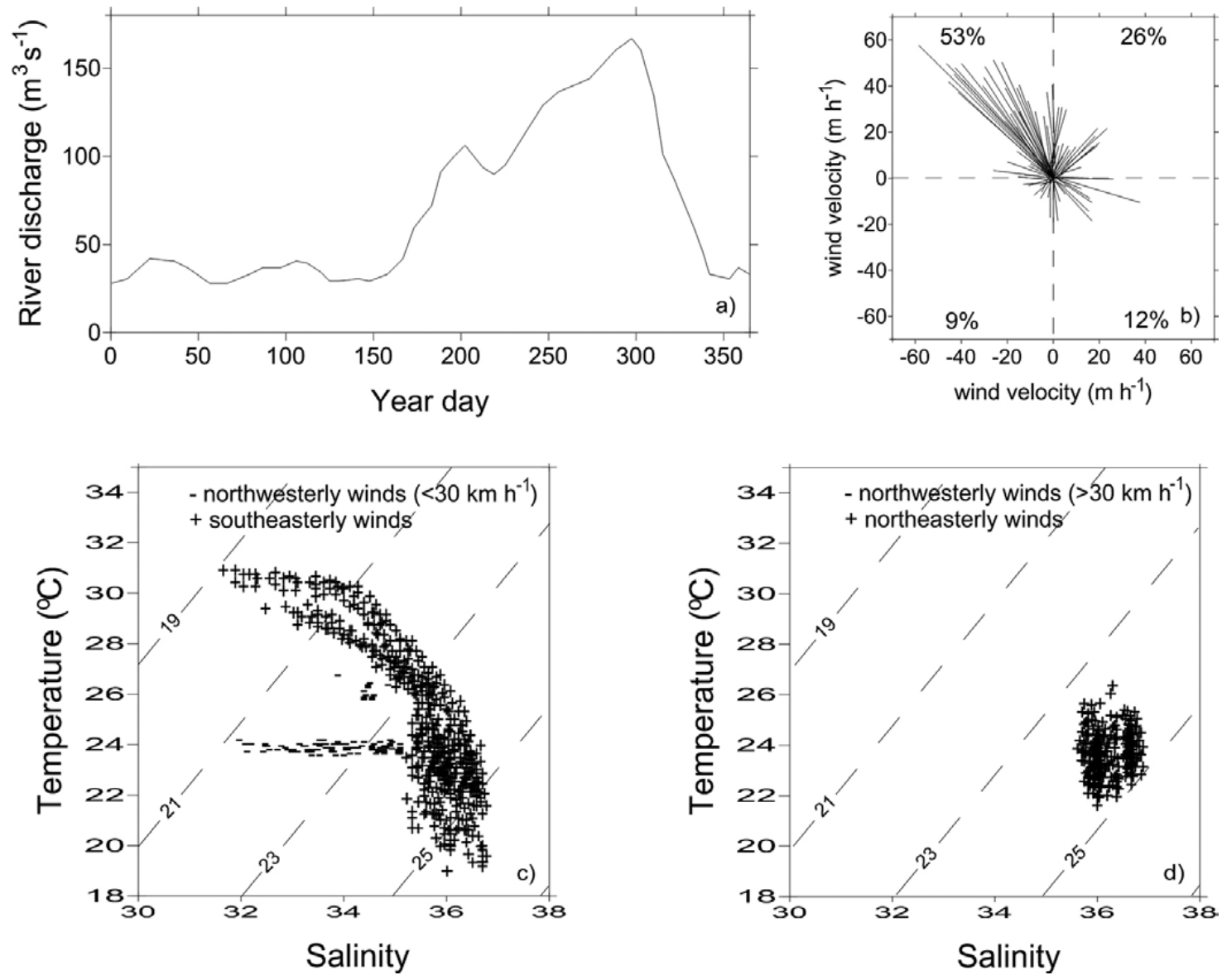

Fig. 4. - A, Jamapa River discharge; B, wind rose; C, the T-S diagram during northwesterly and southeasterly wind conditions (parallel to the isobaths); and $\mathrm{D}$, strong ( $>30 \mathrm{~km} \mathrm{~h}^{-1}$ ) northwesterly and northeasterly wind conditions in 2008 .

Arandía et al. 2016). The residual time within the system is approximately 5 days, but due to current rectification some of the larvae could stay near the reefs for up to 45 days in the northern and 40 days in the southern reefs, as was determined by calculating the residual time using the volume flux around the reefs.

To prove that the rectification of the current is due to the abrupt bathymetric changes, four ADPs were anchored near the southeasternmost reef (Fig. 1), and the velocities were then rotated to show them as parallel and perpendicular to the coast. When currents were rectified through bathymetric constriction, the parallel component of the flow was found to be significantly higher than the perpendicular component. It was found that the vertically integrated currents always moved parallel to the reef coast, regardless of the wind velocity or the primary current pattern observed in adjacent waters. The correlation between the wind velocity and the vertically integrated current velocities was always below 0.38 for the $x$-axis and 0.46 for the $y$-axis for the four points. This pattern suggested that the currents were rectified by the reef, moving around the reef rather than moving in the same direction as the wind (wind-induced currents). The calculated relative vorticity suggested a cyclonic movement (positive vorticity) from November to May 2008 and an anticyclonic movement (negative vorticity) from January to April 2008. This is different than in most reef areas, where the vorticity remains the same (positive or negative) throughout the year. In the western Gulf of Mexico the vorticity around the reefs changes owing to current direction, making it a sink for larvae in summer and a source of ichthyoplankton organism in winter when currents moves southward.

As observed with both the Lagrangian and Eulerian analyses of current velocities, the dominant current velocities had a northwest-southeast dominant component. The currents were parallel to the coast and suffered some rectifications due to the abrupt bathymetric changes produced by the presence of the reefs and islands. The water near the reefs always moved parallel to the reef, regardless of the wind direction. The correlation between the wind and the near reef currents was always below 0.46 , whereas the correlation between the "open water" currents and the wind was always above 0.72 . During the winter, the dominant southward currents should bring relatively cold water to the system because these currents carry water from the northwestern Gulf of Mexico, whereas during the summer, the dominant northward currents should bring warmer water from the Campeche Bay and the Caribbean Sea.

Cross-isobath surface currents seem to be very large near the Jamapa River and around the reefs (Fig. 2 ). During the rainy season, from June to November (Fig. 4), the river and sewer discharge increase the cross-isobath velocity near the coast, while the current rectification produced by the reefs (merged and submerged) accelerates the cross-isobath flow. It 

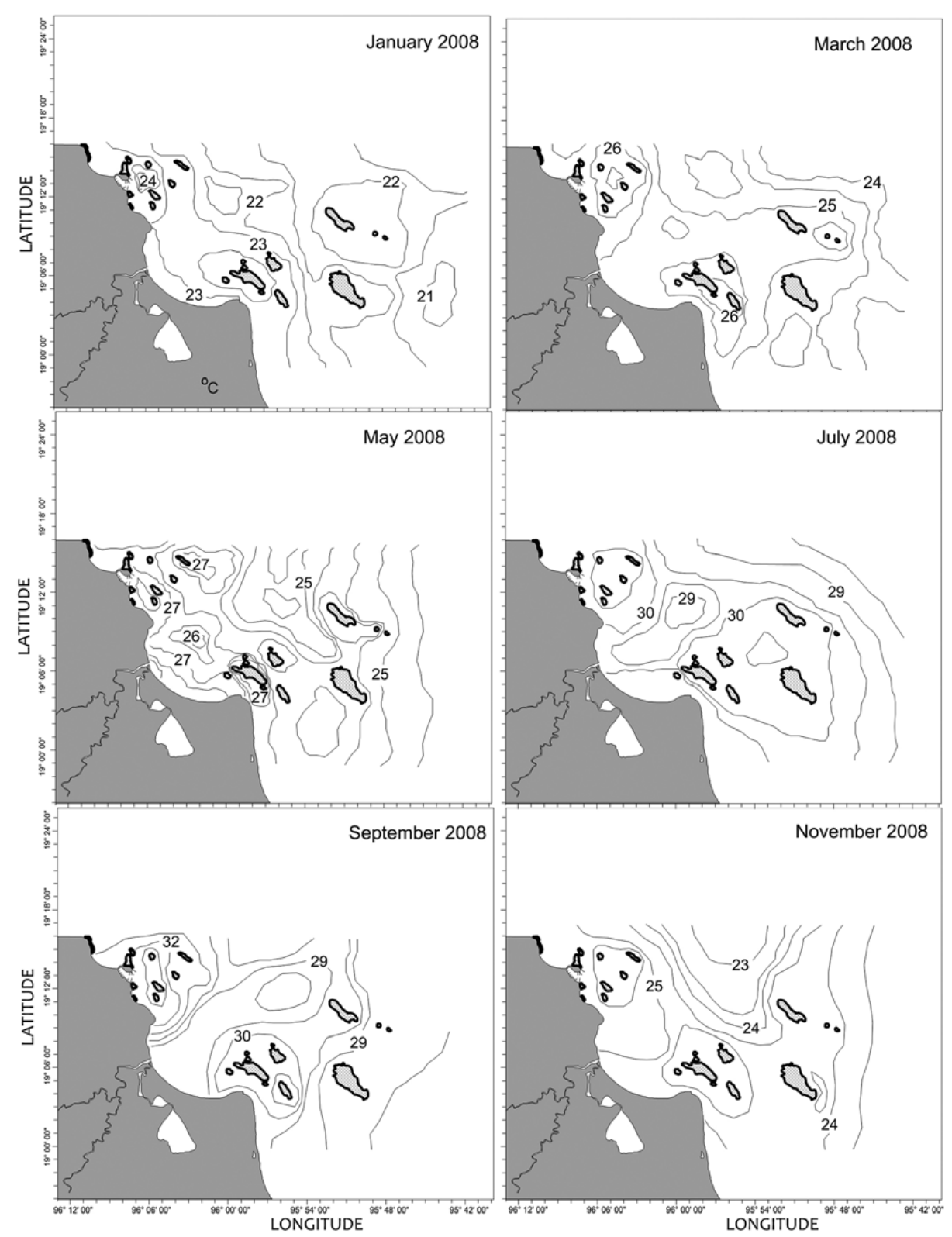

Fig. 5. - The residual sea surface temperature ( $0.5 \mathrm{~m}$ depth) in degrees Celsius $\left({ }^{\circ} \mathrm{C}\right)$ recorded on 18 January, 21 March, 16 May, 18 July, 19 September and 21 November 2008.

was found that wind and current directions were well correlated at a distance of more than $2 \mathrm{~km}$ from the coast. This will produce large cross-isobath surface currents with northeasterly, easterly, southwesterly or westerly winds. According to the wind rose, using daily average velocities for 2008 , it was found that the dominant winds were northwesterly, followed by northeasterly (Fig. 4). This result differed from that reported by Salas-Pérez et al (2012); the discrepancy could be attributed to a possible underestimation of their east-west component due to a scale deformation.

\section{Hydrographic variations}

Sea surface temperature (SST) recorded in 2008 varied from $22^{\circ} \mathrm{C}$ in winter to $32^{\circ} \mathrm{C}$ in summer (Fig.
5). The highest temperatures were observed over the northern coral reefs due to the shallowness of the area and the relatively weak velocities $\left(<30 \mathrm{~cm} \mathrm{~s}^{-1}\right)$ compared with the southern coral reef area. Mateos-Jasso et al. (2012) show the existence of an upwelling in the VRS. The lower temperatures in the southern reef area, where the strongest velocities were observed, were not related to this phenomenon. It was found that the southeasterly winds (upwelling conditions) were not related to a well-mixed water column (Fig. 4). Southeasterly wind conditions were found to be related to a well-stratified water column, with warm temperature at the surface and cold-salty water at the bottom. The well-mixed water column was related to northeasterly and strong northwesterly $\left(>30 \mathrm{~km} \mathrm{~h}^{-1}\right)$ wind conditions, neither of which are upwelling conditions. Therefore it was found that the lower temper- 
atures were most likely related to advective processes from the open ocean toward the VRS. The relatively weak velocities observed over the northern coral reef area were attributed to the proximity to the reef, and to the shallowness of the area (bottom friction). Due to the shape of the coast line, the Cape of Anton Lizardo (Fig. 1) protects the northern reef area from the southerly winds during the summer season (SalasMonreal et al. 2009b). From November to May, the temperatures ranged from $22^{\circ} \mathrm{C}$ to $25^{\circ} \mathrm{C}$. The lower temperatures were attributed to the seasons (winter and autumn), which are characterized by strong northerly and northeasterly winds, locally termed "northern" (Salas-Monreal et al. 2009b), and to the current direction, which brings relatively cold water from the northwestern Gulf of Mexico. As observed in Figure 5 , the horizontal temperature gradients were not as high as expected $\left(2^{\circ} \mathrm{C}\right.$ in $\left.10 \mathrm{~km}\right)$. A higher horizontal temperature gradient was expected due to the depth differences between the two reef areas; the shallow reef area (northern reefs) was expected to be hotter than the deeper area (southern reefs). The relatively homogeneous temperature within the VRS was also attributed to the water velocity (Fig. 3), which moves water (suspended particles) from the northern to the southern reef area in approximately $24 \mathrm{~h}$. Finally the river discharges from the Jamapa River may suggest a higher temperature gradient within the area, but this was not observed owing to the weak river discharge of the Jamapa River (Fig. 4) during most of the year $\left(1.9 \times 10^{6} \mathrm{~m}^{3}\right.$ year $\left.^{-1}\right)$. From July to September, the SST was $30^{\circ} \mathrm{C}$, with a spatial variation of up to $2^{\circ} \mathrm{C}$, similar to the coldest months (Fig. 5). The warmer surface (1 $\mathrm{m})$ temperatures observed during the summer and spring were also attributed to the relatively weak current velocities compared with the coldest months and to the northerly current direction, which brings warm water from the Bay of Campeche and the Caribbean Sea. The isothermals were observed in a circular shape around the reefs. This pattern was attributed to the shallowness of the reefs, which allowed the solar irradiation to heat the entire water column $(<15 \mathrm{~m})$, and to the currents, which were parallel to the reef coast (in a circular shape), isolating them from external deeper water cooling.

The coldest months of the year were observed from October to March (Fig. 6) and the warmest from June to September. During the warmer months, the vertically integrated salinity and density (Fig. 6) dropped. This drop was attributed to the rainy season (Fig. 4) because the area studied is directly affected by one river located in the middle section of the bay and two rivers located approximately $60 \mathrm{~km}$ toward the north (La Antigua River) and approximately 80 $\mathrm{km}$ toward the south (Papaloapan River) of the bay. During the coldest months, the vertically integrated salinity and density increased. This increase was attributed to the current velocities that brought salty open water to the bay, in contrast to the warmer months when the currents (northeastwards) pushed the less salty water from the Papaloapan River to the VRS. It was found that the nearshore surface $(1 \mathrm{~m})$ temperature was larger than the offshore temperature during each month. However, there was great seasonal variability related to less mixing due to weaker winds and smaller waves in summer than in winter. The space variation was $1 \times 10^{-4}{ }^{\circ} \mathrm{C} \mathrm{m}^{-2}$ and the time variation was $1.9 \times 10^{-2}{ }^{\circ} \mathrm{C}$ day $^{-1}$.

The chlorophyll- $a$ levels were recorded once a month in 2008 and did not exhibit a significant variation (Fig. 6), as the levels were always approximately $2 \mu \mathrm{g} \mathrm{m}^{-1}$. However, in January the observed value was $3.2 \mu \mathrm{g} \mathrm{m} \mathrm{m}^{-1}$. The increased levels were attributed to strong northeasterly winds that mixed the entire water column (Fig. 4) with resuspended nutrients from the seafloor. The salinity and density were highly correlated $\left(\mathrm{r}^{2}=0.87\right)$ but the temperature and chlorophyll- $a$ levels were not $\left(r^{2}=0.42\right)$.

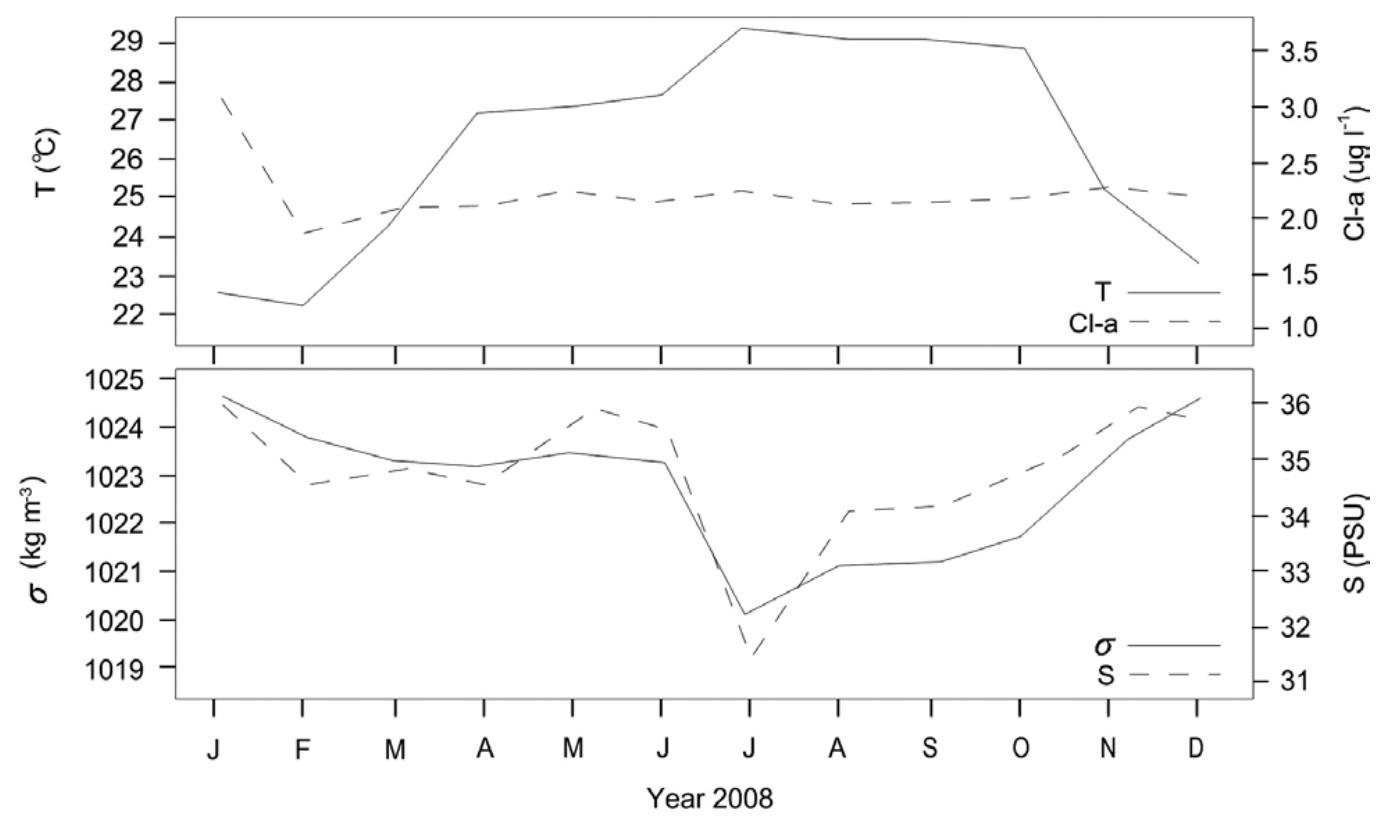

Fig. 6. - Yearlong temperature, chlorophyll-a levels, density and salinity from January to 10 December 2008. 


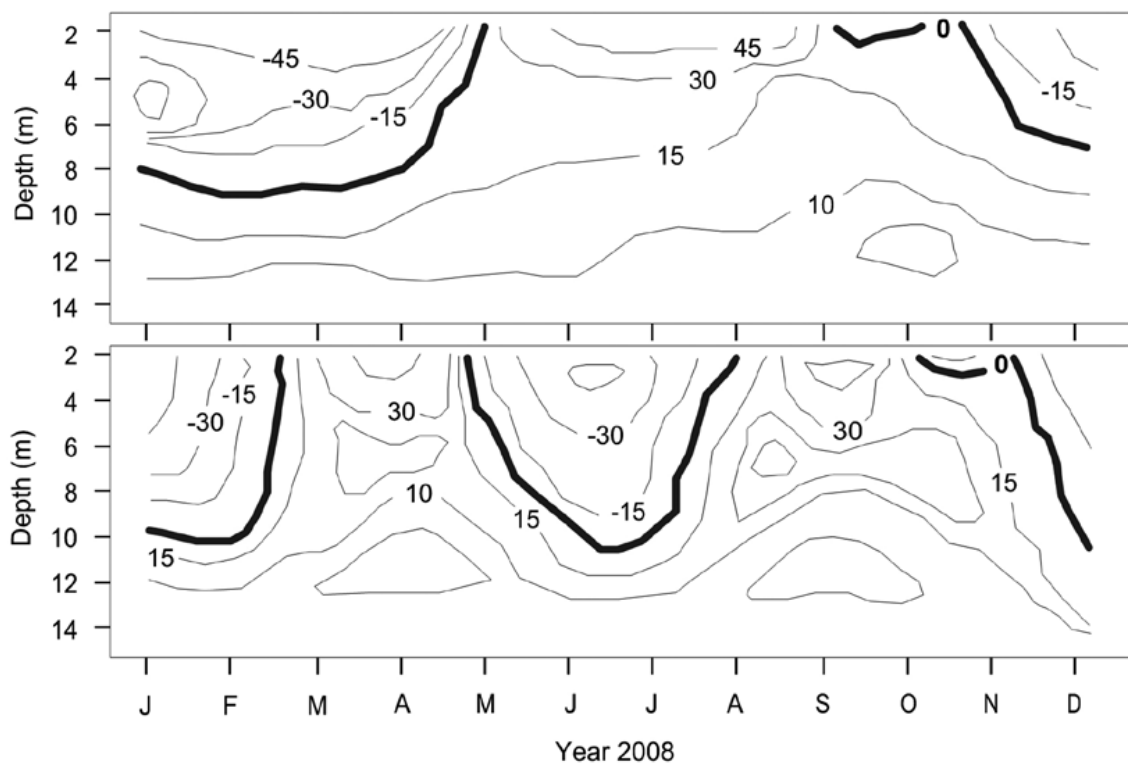

Fig. 7. - Residual contours of the a) $u$ (east-west) and b) $v$ (north-south) current velocities in cm s ${ }^{-1}$ from 6 January to 10 December 2008 . In this case, the $u$ component is perpendicular to the isobaths and the $v$ component is parallel to the isobaths.

\section{Vertical variations}

The current velocity (Fig. 7) observed at the anchored station (Fig. 1) showed baroclinic properties, as the current velocities changed direction within the water column. The north-south component of the current $(v)$ was always higher than the east-west component $(u)$. The instrument was deployed at the $15 \mathrm{~m}$ isobath with the north-south component of the current travelling along the isobath and the east-west component travelling across the isobath. Wind effects were observed during the cold months to depths of up to 8 $\mathrm{m}$. The wind direction was highly correlated with the current direction from the surface down to $8 \mathrm{~m}$ in depth $\left(r^{2}>0.76\right)$. Below this depth and during the warmer months, the currents moved in a northward direction. During the warmer months, the wind direction and the vertically integrated water velocities were highly correlated $\left(r^{2}>0.68\right)$. A westward direction of the currents

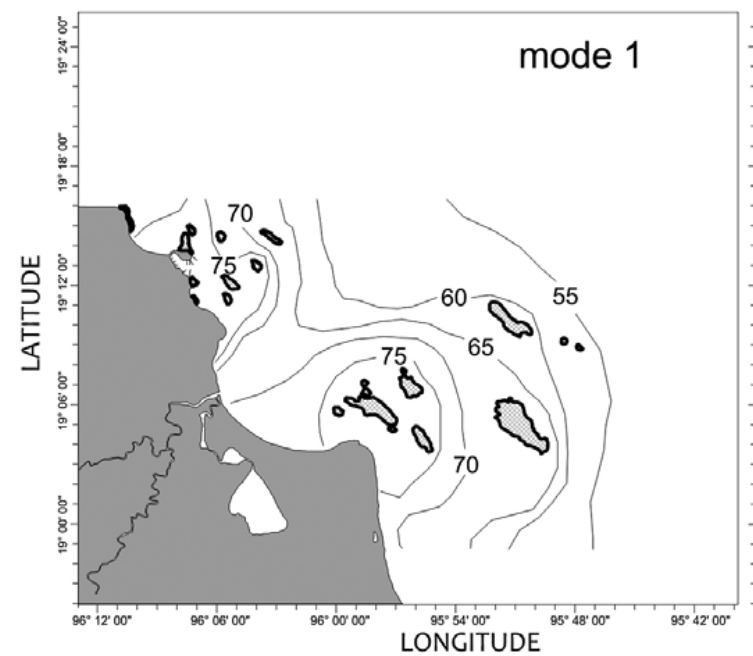

(u) was also observed during the period of northeasterly and strong northwesterly winds (locally called nortes) and during the period of southeasterly winds (locally called suradas). This wind pattern was observed because the local winds had a predominant northwesterly direction (Fig. 4). However, during the cold months, the current direction at depths below $9 \mathrm{~m}$ and the wind direction were not correlated $\left(\mathrm{r}^{2}<0.34\right)$. At depths below $9 \mathrm{~m}$, the current moved northeastward regardless of the wind velocities, suggesting that the advection term in the moment equation should be important, and also that there could be a connection between the ichthyoplankton organisms located below $9 \mathrm{~m}$ depth in the southern and northern reef areas of the VRS.

When the wind relaxed, the flow moved eastward, as was observed with the vertically integrated current velocities. This feature suggests that the pressure gradient term should be locally important. At depths below $10 \mathrm{~m}$, the current always moved northeastward,

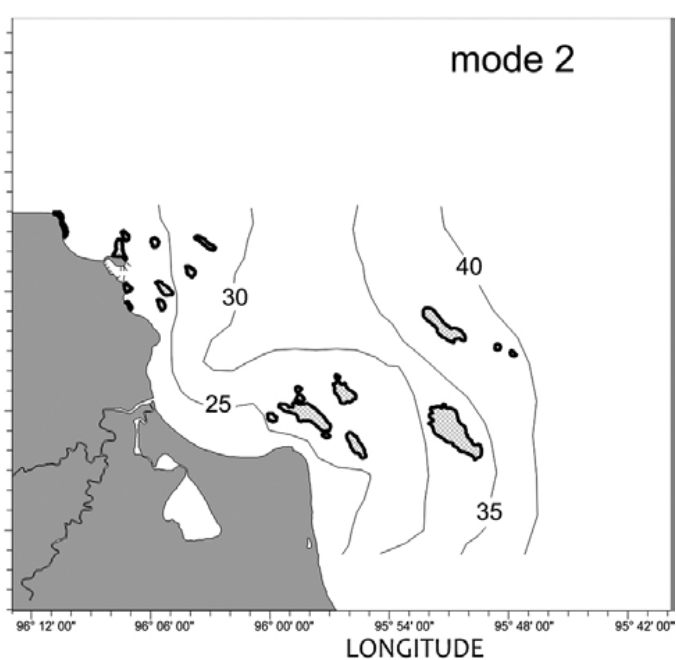

Fig. 8. - Mode 1 and 2 of the empirical orthogonal functions (EOF) of the water speed as calculated from the monthly yearlong data set from January to November 2008. 

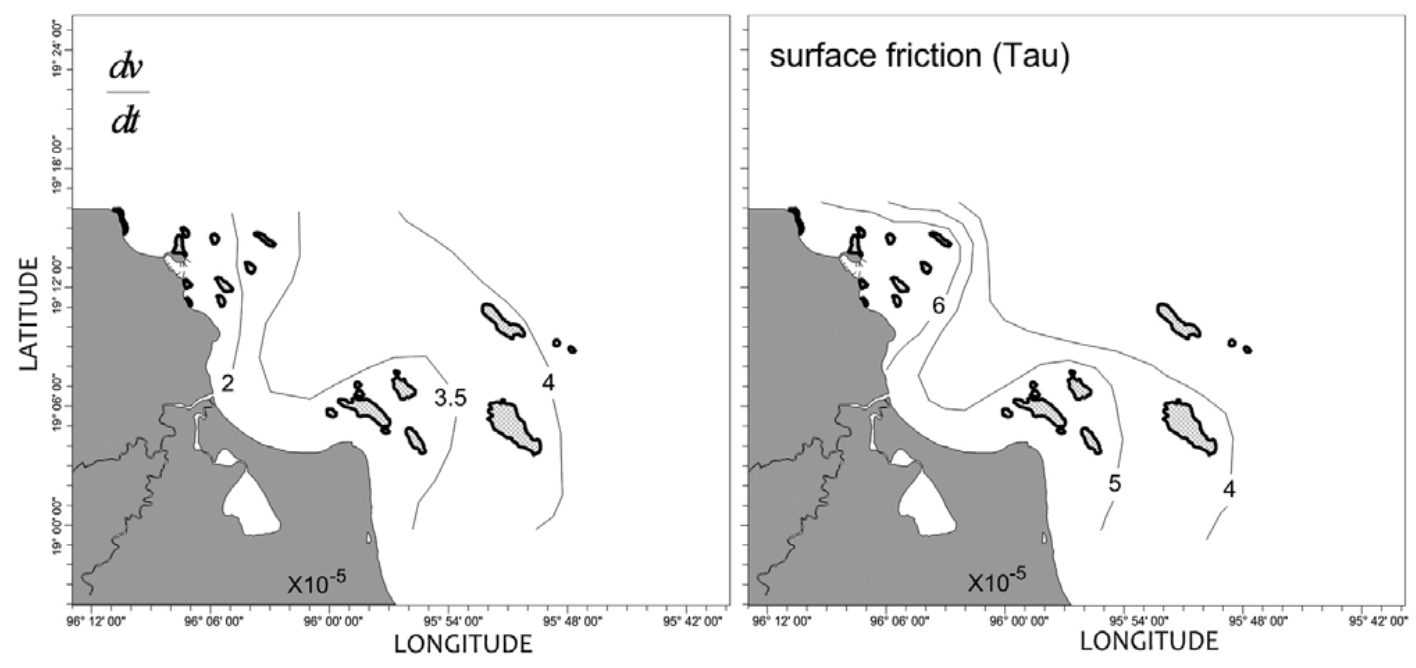

Fig. 9. - Annual mean principal modes of the current speed, calculated from the monthly yearlong data set from January to November 2008.

suggesting that this may be the dominant circulation of the western Gulf of Mexico without the influence of the wind. According to the EOF applied to the current speed using the yearlong time series of each transect point, only two modes were detected as being responsible for explaining more than $93 \%$ of the total variance (Fig. 8) in 2008. The first mode was higher close to the reefs, whereas the second mode was higher toward the open waters. The first mode was attributed to friction (Fig. 9) due to the wind (surface friction) and the second mode was attributed to advection.

Friction (along both the surface and the bottom) had a higher effect in shallow waters because the friction can affect the entire water column, whereas advection had a higher effect in open water or toward the open sea (Salas-Monreal et al. 2009b). However, given the baroclinic behaviour of the flow at the anchored station and the observed barotropic adjustment (eastward flow from surface to bottom) under periods of wind relaxation, the pressure gradient term should be important to the local dynamics. This relaxation was only observed after episodes of strong winds. The strong winds occur on average 38 times a year (Salas-Pérez et al. 2012). Therefore, below $9 \mathrm{~m}$ depth there could be a direct connection between ichthyoplankton and coral larvae in the southern and northern reef areas of the VRS.

\section{CONCLUSIONS}

Current velocities, which were measured using an ADCP and temperature, salinity and density data sets from a CTD, were recorded bimonthly during the year 2008 in a tropical coral reef system to elucidate the effects of the abrupt bathymetric changes on current rectification and shallow reef temperature variations. According to the EOF, the dominant terms in the shallow reef system were advection and friction; both terms explained more than $90 \%$ of the total variance. Mode 1 ranged between $55 \%$ and $75 \%$ and mode 2 ranged between $25 \%$ and $40 \%$ in the entire reef system area. The surface current velocities showed the dominance of the $v$ component (north-south direction, parallel to the coast and to the isobaths), which was attributed to surface friction (winds). The data clearly showed that the coral reefs produced current rectification even when the reefs were not emerged (1 $\mathrm{m}$ depth) because the currents moved parallel to the reefs regardless of the wind velocity (surface friction) and to the mesoscale current pattern (advection). Surface temperature and chlorophyll-a levels were not correlated in 2008. Salinity, temperature and density were correlated but the chlorophyll- $a$ levels always showed a constant value of close to $2 \mu \mathrm{g} \mathrm{l}^{-1}$. This finding was attributed to local river discharges and to the reef itself, which is a high-productivity area. The residual current velocities throughout the year (2008) never reached more than 50 $\mathrm{cm} \mathrm{s}^{-1}$, whereas the temperature varied from $21^{\circ} \mathrm{C}$ to $30^{\circ} \mathrm{C}$ throughout the year, with the highest temperature near the coast and the reefs due to the shallowness of the areas and the low turbidity of the water near the reefs. A direct connection between the ichthyoplankton and coral larvae below $9 \mathrm{~m}$ depth from the southern and northern reef areas of the VRS was also suggested, but above $9 \mathrm{~m}$ depth there is a physical barrier for the planktonic organisms due to the Jamapa River. Finally, the data showed that the entire water column was only able to mix under northeasterly and strong $(>30 \mathrm{~km}$ $\mathrm{h}^{-1}$ ) northwesterly wind conditions.

\section{ACKNOWLEDGEMENTS}

This project was supported by CONACYT grant "Ciencia Basica 78773 and 158152". We would like to thank the crew and students who helped during each of the sampling stages for their dedication. The comments of Dr. Arnoldo Valle-Levinson help to improve the content of this manuscript.

\section{REFERENCES}

Agardy T. 2000. Information needs for marine protected areas: Scientific and societal. Bull. Mar. Sci. 66(3): 875-888.

Allende-Arandía M.E., Zavala-Hidalgo J., Romero-Centeno R., et al. 2016. Analysis of ocean current observations in the northern Veracruz Coral Reef System, Mexico: 2007-12. J. Coast. Res. 
32: $46-55$ http://dx.doi.org/10.2112/JCOASTRES-D-14-00148.1

Becerro M.A., Bonito V., Paul V.J. 2006. Effects of monsoondriven wave action on coral reefs of Guam and implications for coral recruitment. Coral Reefs 25: 193-199. http://dx.doi.org/10.1007/s00338-005-0080-7

Biggs D.C. 1992. Nutrients, plankton, and productivity in a warmcore ring in the western Gulf of Mexico. J. Geophys. Res. 97: 2143-2154. http://dx.doi.org/10.1029/90JC02020

Chacon-Gomez I.C., Salas-Monreal D., Riveron-Enzastiga M.L. 2013. Current pattern and coral larval dispersion in a tropical coral reef system. Cont. Shelf Res. 68: 23-32. http://dx.doi.org/10.1016/j.csr.2013.08.014

Dubranna J., Pérez-Brunius P., López M., et al. 2011. Circulation over the continental shelf of the western and southwestern Gulf of Mexico. J. Geophys. Res. 116(C8): C08009. http://dx.doi.org/10.1029/2011JC007007

Emery W.J., Thompson R.E. 2001. Data analysis methods in physical oceanography, 2nd revised edition, Elsevier, Amsterdam.

Goreau T.J., Hayes R.L. 1994. Coral bleaching and ocean "hot spots". Ambio 23: 176-180.

Holliday D.V., Pieper R.E. 1980. Volume scattering strengths and zooplankton distributions at acoustic frequencies between 0.5 and 3 MHz. J. Acoust. Soc. Am. 67(1): 135-146. http://dx.doi.org/10.1121/1.384472

Mateos-Jasso A., Zavala-Hidalgo J., Romero-Centeno R., et al. 2012. Variability of the thermohaline structure in the northern Veracruz Coral Reef System, Mexico. Con. Shelf Res. 50(51): 30-40. http://dx.doi.org/10.1016/j.csr.2012.10.001

Monreal-Gomez M.A., Salas-de-León D.A., Velasco-Mendoza H. 2004. La hidrodinámica del Golfo de México, In: Caso M., Pisanty I., Escurra E. (eds). Diagnóstico ambiental del Golfo de México. Vol. 1. Instituto Nacional de Ecología. Mexico. pp. 47-68.

Salas-de-Leon D.A., Diaz-Flores M.A., Monreal-Gómez M.A. 2004a. Circulation and vorticity in the Southern Gulf of Mexico. In: Schroeder W (ed) Hans Ertel Memorial Book, German Commission of History of Geophysics and Cosmical Physics. pp. 229-243.

Salas-de-Leon D.A., Monreal-Gomez M.A., Signoret M., et al. 2004b. Anticyclonic-cyclonic eddies and their impact on near- surface chlorophyll stocks and oxygen supersaturation over the Campeche Canyon, Gulf of Mexico. J. Geophys. Res. 109: C05012. http://dx.doi.org/10.1029/2002jc001614

Salas-Perez J J., Granados-Barba A. 2008 Oceanographic characterization of the Veracruz reefs system. Atmosfera 21: 281-301.

Salas-Perez J.J., Salas-Monreal D., Arenas-Fuentes V.E., et al. 2008. Tidal characteristics in a coral reef system from the western Gulf of Mexico. Cienc. Mar. 34(4): 467-478.

Salas-Perez J.J., Salas-Monreal D., Monreal-Gomez M.A., et al. 2012. Seasonal absolute acoustic intensity, atmospheric forcing and currents in a tropical coral reef system reference. Est. Coast. Shelf Sci. 100: 102-112. http://dx.doi.org/10.1016/j.ecss.2012.01.002

Salas-Monreal D., Valle-Levinson A. 2009a. Sea-Level slopes and volume fluxes produced by atmospheric forcing in estuaries: Chesapeake Bay case study. J. Coast. Res. 24(2B): 208-217.

Salas-Monreal D., Salas-de-León D.A., Monreal-Gomez M.A., et al. 2009b. Current rectification in a tropical coral reef system. Coral Reefs 28(4): 871-879. http://dx.doi.org/10.1007/s00338-009-0521-9

Storlazzi C.D., McManus M.A., Logan J.B., et al. 2006. Cross-shore velocity shear, eddies and heterogeneity in water column properties over fringing coral reefs: West Maui, Hawaii. Cont. Shelf Res. 26: 401-421. http://dx.doi.org/10.1016/j.csr.2005.12.006

Trump C.L., Marmorino G.O. 1997. Calibrating a gyrocompass using ADCP and DGPS data. J. Atmos. Ocean Tech. 14: 211-214. http://dx.doi.org/10.1175/1520-0426(1997)014<0211:CAGUA A $>2.0 . \mathrm{CO} ; 2$

Velasco G.G., Winant C.D. 1996. Seasonal patterns of wind stress and wind stress curl over the Gulf of Mexico. J. Geophys. Res.: Oceans 101(C8): 18127-18140. http://dx.doi.org/10.1029/96JC01442

Wilkinson C., Souter D. (eds). 2008. Status of Caribbean coral reefs after bleaching and hurricanes in 2005. Global Coral Reef Monitoring Network, and Reef and Rainforest Research Centre, Townsville.

Zavala-Hidalgo J., Morey S.L., O’Brien J.J. 2003. Seasonal circulation on the western shelf of the Gulf of Mexico using a high resolution numerical model. J. Geophys. Res.: Oceans (19782012), 108(C12): 3389. 